\title{
A robust automated system for detecting and recognising the digit of electrical energy consumption number of the postpaid kWh-meter
}

\author{
Herryawan Pujiharsono ${ }^{1,2 *}$, Hanung Adi Nugroho ${ }^{1}$, Oyas Wahyunggoro ${ }^{1}$ \\ ${ }^{1}$ Department of Electrical Engineering and Information Technology, Faculty of Engineering, Universitas Gadjah Mada \\ ${ }^{2}$ Faculty of Telecommunication and Electrical Engineering, Institut Teknologi Telkom Purwokerto
}

Article history:

Received: 26 November 2017 / Received in revised form: 29 November 2017 / Accepted: 29 November 2017

\begin{abstract}
Most of the processes of kilowatt-hour meter (kWh-meter) reading in Indonesia are still in manual process which may lead to some problems, such as time consumption and high possibility of data entry errors. Therefore, this study proposes an automated system to minimise these problems. This system is developed for the image with uneven illumination condition and tilted position of stand $\mathrm{kWh}$-meter due to the unavoidable situation while capturing the $\mathrm{kWh}$-meter image. In this study, the illumination problem is solved by local thresholding and the tilted position of stand $\mathrm{kWh}-\mathrm{meter}$ is solved by combination of morphology operations and vertical edge detection on the location detection process and vertical-horizontal projections on the segmentation process. Finally, the numeral recognition is performed by support vector machine (SVM) classifier with zonal density feature as a selected input. The results show that the accuracy of proposed system is $93.55 \%$ on detection location process, $89.38 \%$ on segmentation process, and $78.10 \%$ on numeral recognition process.
\end{abstract}

\section{Introduction}

The digit of electrical energy consumption number $(\mathrm{kWh}-$ numbers) is located in a part of $\mathrm{kWh}-\mathrm{meter}$, called as stand $\mathrm{kWh}$-meter. This number is important for postpaid $\mathrm{kWh}-$ meter record to calculate the monthly electricity bill. Hence, it is always recorded every month. This recording activity is also called as the kWh-meter reading.

The processes of $\mathrm{kWh}-\mathrm{meter}$ reading in Indonesia, especially the process on data entry into Rute Baca Meter ${ }^{\mathrm{a}}$ (RBM) database, are still in manual process and it may cause some problems, such as time consumption and high possibility of data entry errors [1]. The data entry errors raise many complaints from the customers [2]. Hence, the problems need to be minimised by developing automated system for $\mathrm{kWh}$ meter reading processes.

Most of the developed automated system, i.e. Automatic Meter Reading (AMR), is difficult to completely implement in Indonesia because it is prioritized for customers in $41.5 \mathrm{kVA}$ power or over [3]. Moreover, Perusahaan Listrik Negara $(\mathrm{PLN})^{\mathrm{b}}$ recommends the customers who consumed power below $41.5 \mathrm{kVA}$ to use prepaid $\mathrm{kWh}$-meter as replacement or new installation of $\mathrm{kWh}$-meter. However, an automated process of kWh-meter reading is essential since the number of postpaid $\mathrm{kWh}$-meter customers are more than the prepaid

* Corresponding author.

Email: herryawan@ittelkom-pwt.ac.id.
kWh-meter customers. Data in March 2013 shows that there are $86 \%$ customers in Yogyakarta using postpaid kWh-meter [4]. Hence, the automated system of $\mathrm{kWh}-$ meter reading should be developed in other way.

Currently, the kWh-meter reading in Indonesia are supported by camera for capturing the image of kWh-meter. However, the images are used only for verification process [5]. Literally, the images can be exploited to develop an automated system by adopting the general process of vehicle number plate detection and recognition considering of both detected shape have similar characteristics, i.e. rectangle object consisting of several characters that must be recognised. The general principle consists the detection of location, character segmentation and character recognition [6]. Unfortunately, some conducted research for developing the image-based automation system are still constrained by uneven illumination condition and tilted position of stand kWh-meter on kWh-meter image [1], [7]-[10]. An uneven illumination makes the stand $\mathrm{kWh}$-meter object difficult to separate from other objects or background on the binary images. Moreover, the tilted position of stand $\mathrm{kWh}$-meter may disrupt the process of location detection and segmentation. On the other hand, this condition is

${ }^{a}$ Rute Baca Meter (RBM) is a document containing the route of customer data and the kWh-numbers in each customer data

${ }^{b}$ Perusahaan Listrik Negara (PLN) is an Indonesian state-owned company tasked with taking core of all aspects of electricity in Indonesia 
unavoidable when the image of $\mathrm{kWh}$-meter capturing process is conducted outside the building, with the sunlight beams affects and higher position of stand kWh-meter compare with its ideal position.

This study aims to design a system that can automatically detect and recognise the displayed numbers on stand $\mathrm{kWh}$ meter through $\mathrm{kWh}$-meter image without the aforementioned constrains. The recognised numbers are stored on Rute Baca Meter database; hence, the kWh-meter images are used not only for verification process, but also in assisting and speeding up the clerk in the $\mathrm{kWh}$-meter reading process.

Illumination problem on $\mathrm{kWh}$-meter image can be solved by local thresholding in order to separate the $\mathrm{kWh}$ meter from other objects or background. Local thresholding is performed to process the bad quality image due to uneven illumination. As a result, local thresholding is successful to separate the letters from its background so that the letters can be clearly read [11]-[13].

The identification of stand kWh-meter position can be solved by combination of morphology operations and vertical edge detection on detection process of location [14]-[16], and then vertical-horizontal projections on segmentation process [6], [17]-[21]. Vertical edge detection is commonly performed in vehicle number plate detection process because the characters of number plate are horizontally arranged which resulting in lots of vertical edges on the image. Morphology operations are commonly performed to minimise disrupted objects and unnecessary edges so that the location detection process accuracy can be increased. Vertical and horizontal projections are commonly used in segmentation of vehicle number plate and document image because they are simple, fast and efficient.

The results of segmentation process are inputted to Support Vector Machine (SVM) for classification with statistical features as its inputs. The SVM classifier has some advantages when it is compared to Artificial Neural Network (ANN). Whilst ANN only finds local optimal solution, SVM is capable to find global optimal solution [22]. Moreover, SVM classifier is also proven in achieving higher accuracy compare with k-Nearest Neighbour (k-NN) and Probabilistic Neural Network (PNN) classifiers in Gumurkhi letters recognition case [23].

\section{Materials and Methods}

Fig. 1 shows the architecture of the proposed system consisting of stand kWh-meter location detection [24], number area segmentation, and numeral recognition process. There are $155 \mathrm{kWh}$-meter images as the input of the proposed system which taken from PT. PLN Yogyakarta database. They consist of colour images in $320 \times 240$ pixels resolution with various conditions of illumination and stand $\mathrm{kWh}-$ meter position.

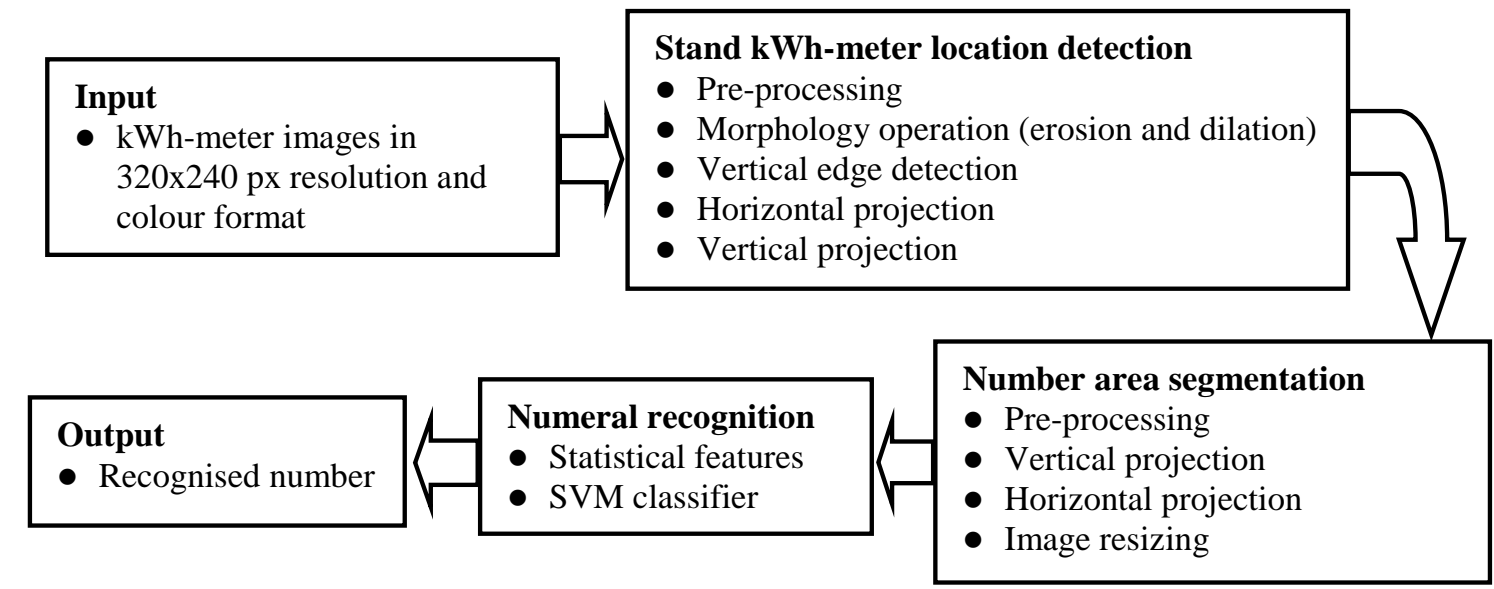

Fig. 1. Architecture of the proposed system

\subsection{Stand kWh-meter Location Detection}

The steps of this process refers to [24], as shown in Fig. 2. In order to minimise the detection error, the detection process in the work of [24] is improved by changing the size of SE matrix of morphology operation, either on erosion or dilation operation, from fixed value to flexible value and giving the iteration from morphology operation to the last step for decreasing size of SE matrix on each iteration. The detection process is iterated until the size ratio of the extracted object is less than the expected ratio. In this study, the expected ratio is limited from 3 to 7 .

\subsection{Number Area Segmentation}

The extracted stand $\mathrm{kWh}$-meter from the location detection process is inputted on this process and the output is the number area. The maximum number of the segmented area is five segments because the stand $\mathrm{kWh}-$ meter consist of five digits.

The first step on this process is pre-processing because the digits on extracted stand kWh-meter, as shown in Fig. 3(a), are unclear and difficult to be recognised on the numeral recognition process. Pre-processing is performed by rethresholding the grayscale image of extracted stand $\mathrm{kWh}$ meter adaptively using pixel subtraction method [25]. The filter used for pixel subtraction method is mean filter with the window size is determined from quarter of the extracted stand $\mathrm{kWh}$-meter height and the value of global thresholding $(\mathrm{C})$ is 3. Then, the result of re-thresholding, as shown in Fig. 3(b), is operated with the previous binary image of extracted stand kWh-meter on Fig. 3(a) using AND operator to minimise the 
noises, as shown in Fig. 3(c).

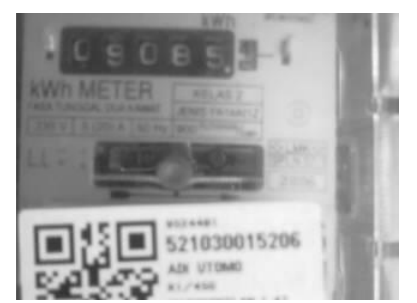

(a) grayscaling

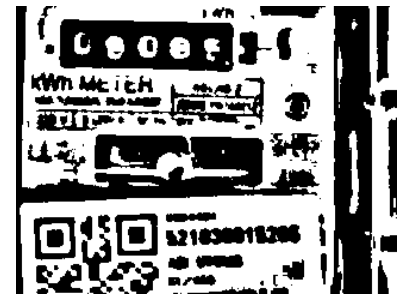

(b) local thresholding

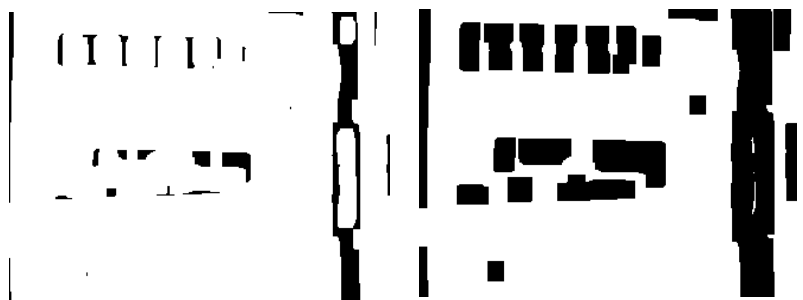

(c) erosion operation

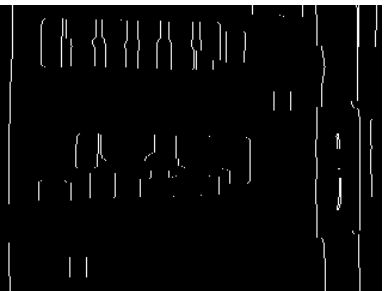

(e) vertical edge detection

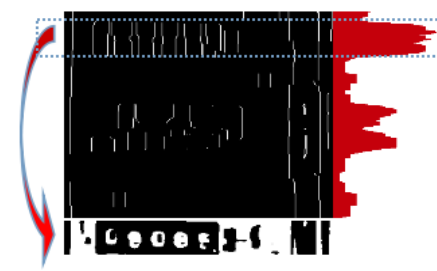

(f) horizontal projection

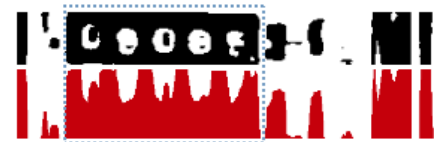

I

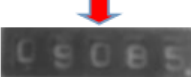

(g) vertical projection

Fig. 2. The process of location detection [24]

\section{8}

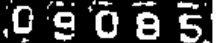

(b) re-thresholding

\section{5}

(c) after preprocessing

Fig. 3. Pre-processing

The next step is vertical and horizontal projections. In order to solve the tilted position of stand $\mathrm{kWh}$-meter on segmentation process, firstly, vertical projection is performed to separate all of number area on extracted stand kWh-meter, as shown is Fig. 4(a). Afterwards, horizontal projection is performed to remove unused region on each number area and minimise the height, as shown in Fig. 4(b).

Vertical projection counts the black pixel on each column of the extracted stand $\mathrm{kWh}-$ meter in vertical direction. The lower area on the vertical projection histogram indicates the number area because the area is dominated by the white pixel. Each number area is segmented from the extracted stand
kWh-meter based on that information.

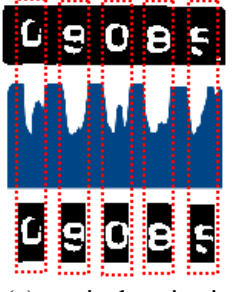

(a) vertical projection

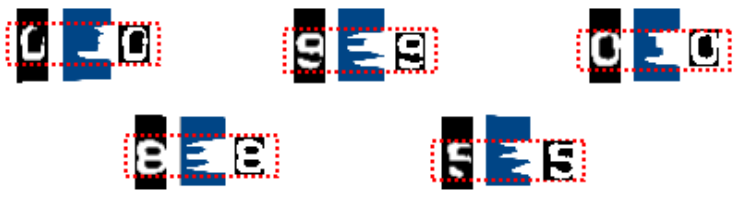

(b) horizontal projection

Fig. 4. Vertical and horizontal projections for segmentation process

Horizontal projection counts the black pixel on each row of each number area by horizontal direction. The higher area on the top and the bottom of the histogram from horizontal projection shows the unused region. The height of each number area is minimised based on that information.

The last step is image resizing as the post-processing. Image resizing normalises the size of number area to the same size because the size of number area may be different after vertical and horizontal projections. The used image resizing method is subsampling method [26]. It is simple and suitable for the binary image or object because it just copying the nearest pixel value and it does not need calculation as interpolation method. In this study, the resolution of area is set to $32 \times 24$ pixels

\subsection{Numeral Recognition}

Most of the steps in this process refers to the recognition process of Gumurkhi character. The steps consist of the use of statistical features combination (projection histogram, distance profile, zonal density and background directional distribution (BDD)), feature extraction with 10 feature vector sets, as shown in Table 1, and feature selection using 5-fold cross validation [23]. The size of each feature vector in Table 1 is adjusted to the resolution of $32 \times 24$ pixels.

Table 1. The feature vector sets

\begin{tabular}{clc}
\hline $\begin{array}{c}\text { Feature } \\
\text { vector }\end{array}$ & \multicolumn{1}{c}{ Included Features } & Feature Size \\
\hline 1 & Projection Histogram (PH) & 178 \\
2 & Distance Profile (DP) & 120 \\
3 & Zonal Density (ZD) & 24 \\
4 & Background Direction Distribution & 192 \\
& (BDD) & 180 \\
5 & DP + Horizontal and Vertical & 144 \\
6 & Histogram (HVH) & 216 \\
7 & ZD + DP & 252 \\
8 & ZD + BDD & 312 \\
9 & BDD + HVH & 310 \\
10 & BDD + DP & \\
\hline
\end{tabular}


In this study, the feature vectors are respectively inputted to SVM classifier with Radial Basis Function (RBF) kernel, as defined in the following [22].

$$
\begin{gathered}
\max \sum_{i=1}^{l} \alpha_{i}-\frac{1}{2} \sum_{i, j=1}^{l} y_{i} y_{j} K\left(x, x^{\prime}\right) \alpha_{i} \alpha_{j} \\
\text { subject to: } \sum_{i=1}^{l} \alpha_{i} y_{i} \\
0 \leq \alpha_{\mathrm{i}} \leq C, \quad i=1, \ldots, l
\end{gathered}
$$

where

$$
\begin{array}{ll}
x_{i} & \text { : input data } \\
y_{i} & \text { : output data } \\
\alpha_{i} & \text { : lagrange multiplier } \\
C & \text { : parameter for controlling the size of error tolerance }
\end{array}
$$$$
K\left(x, x^{\prime}\right): \text { RBF kernel of SVM classifier }=\exp \left(-\gamma\left\|x-x_{i}\right\|^{2}\right)
$$

with $\gamma$ is parameter of RBF kernel.

SVM requires the training phase to find the optimal value of $\alpha$ (Lagrange multiplier), therefore the hyperplane can accurately classify the input data. On the SVM classifier with RBF kernel, there are two parameters that can be tuned to find the optimal hyperplane, they are $C$ (the parameter for controlling the size of error tolerance between slack variable and margin) and $\gamma$ (parameter of RBF kernel) [27]. In this study, the value of parameter $C$ is tuned manually from $2^{-5}$ to $2^{7}$ and parameter $\gamma$ is tuned manually from $2^{-7}$ to $2^{5}$ for each feature vector in Table 1. The training phase is performed by Sequential Minimal Optimization (SMO) algorithm [28]. In order to solve the multiclass problem, this study used OneAgainst-All (OAA) method that constructs k models of SVM where $\mathrm{k}$ is the number of output class [29]. In this study, there are 10 classes as the output (i.e. the number from 0 to 9 ).

\section{Results and Discussion}

\subsection{Stand kWh-meter Location Detection}

There are $155 \mathrm{kWh}$-meter images inputted in location detection process. This process successfully detected and extracted 145 stand $\mathrm{kWh}$-meters from $155 \mathrm{kWh}$-meter images $(93.55 \%)$. The result shows that after using flexible size of SE matrix of morphology operation, the accuracy is better than [24]. The different size of stand $\mathrm{kWh}$-meter that was failed in [24], is successfully detected and extracted. Some extracted stand kWh-meter is shown in Fig. 5. First and second images are example of different models of $\mathrm{kWh}-$ meter with different size of stand $\mathrm{kWh}$-meter that are successfully extracted by using the flexible size of SE matrix. The other image have similar results to [24].
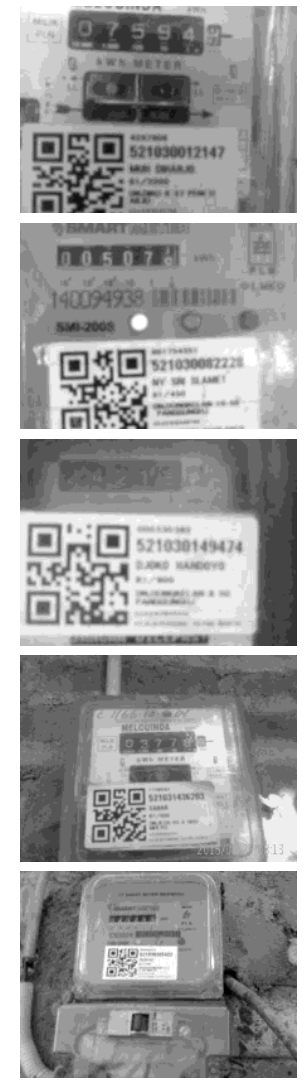

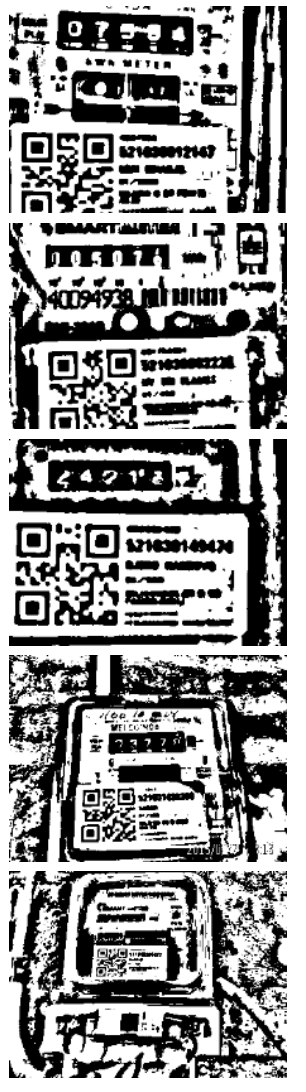

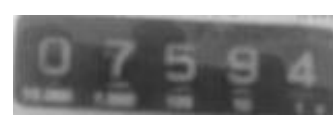

success
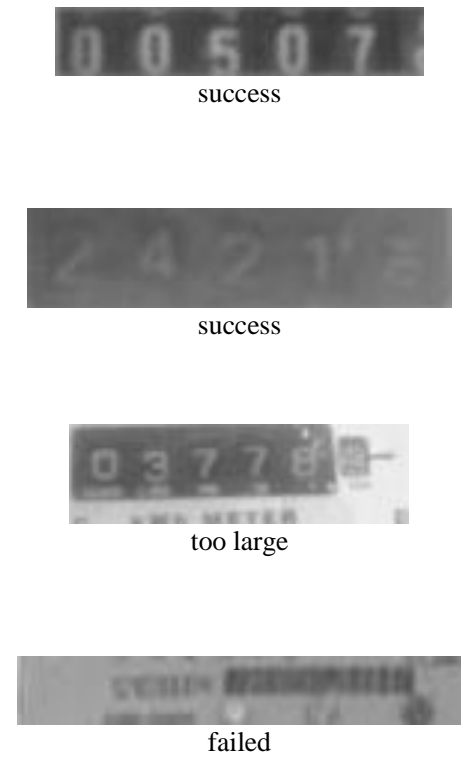

Fig. 5. The result of stand $\mathrm{kWh}-$ meter location detection

\subsection{Number Area Segmentation}

There are 145 extracted stand $\mathrm{kWh}$-meters inputted in this process. This process successfully segmented 648 number areas from $145 \times 5=725$ its total $(89.38 \%)$. Table 2 shows the detail calculation of the successful segmented number area.

Some results of number area segmentation are shown in Fig. 6. The results show that the tilted position of stand kWhmeter has no effect on the process of number area 
segmentation, which shown in the second and the third images of extracted stand kWh-meter. Noise from horizontal or vertical border around the number, just like from second to fourth images, also has no effect on the segmentation process. Besides that, the segmentation process is successful on the movement of turnover number, like shown in the fifth digit of the third image; and clipped number, as the fourth digit of the fourth image. However, the segmentation process is failed by reflected light or other noises that make the numbers on stand $\mathrm{kWh}$-meter are unclear, as the fifth image.
Table 2. The detail calculation of successful segmented number areas

\begin{tabular}{ccc}
\hline $\begin{array}{c}\text { Total of segmented } \\
\text { number area }\end{array}$ & $\begin{array}{c}\text { Total of stand } \\
\text { kWh-meter }\end{array}$ & $\begin{array}{c}\text { The total of number } \\
\text { area }\end{array}$ \\
\hline 5 & 109 & 545 \\
4 & 19 & 76 \\
3 & 9 & 27 \\
0 & 8 & 0 \\
The overall total & 145 & 684 \\
\hline
\end{tabular}

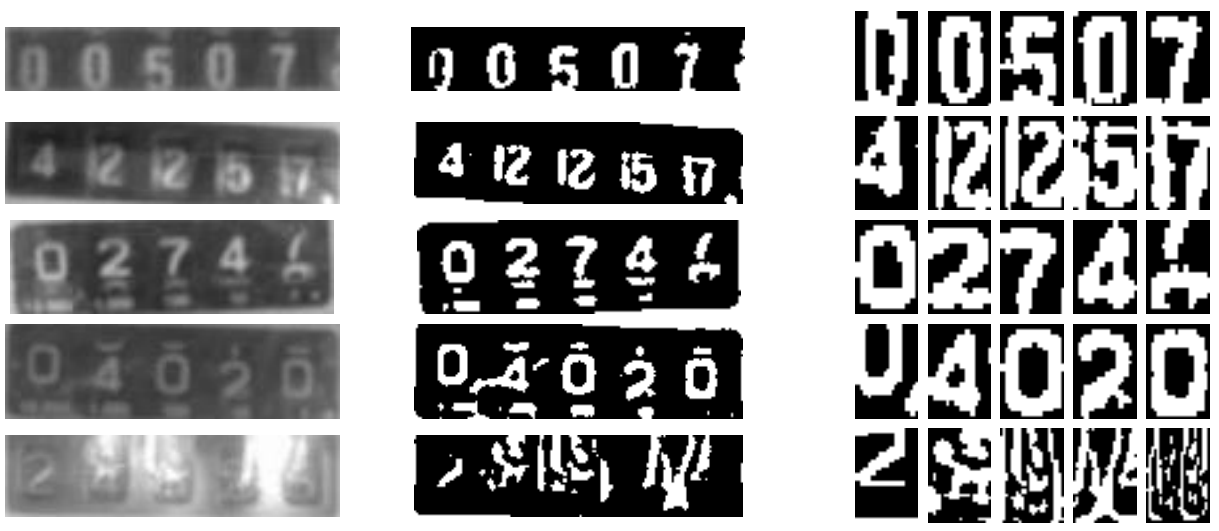

Fig. 6. The results of number area segmentation

\subsection{Numeral Recognition}

There are 684 number of areas inputted for the training phase of SVM classifier to find the optimal value of parameter $(C, \gamma)$ on each feature vector and to select the best feature vector based on the accuracy value using 5-fold cross validation. Table 3 shows the results of training phase of SVM classifier.

Table 3. The result of training phase of SVM

\begin{tabular}{|c|c|c|c|c|c|c|c|}
\hline \multirow{2}{*}{$\begin{array}{l}\text { Feature } \\
\text { Vector }\end{array}$} & \multirow{2}{*}{$\begin{array}{c}\text { Feature } \\
\text { Size }\end{array}$} & \multicolumn{2}{|c|}{ Parameter } & \multirow{2}{*}{ Fold } & \multicolumn{3}{|c|}{ Accuracy } \\
\hline & & $C\left(2^{n}\right)$ & $\mathrm{g}\left(\mathbf{2}^{\mathrm{n}}\right)$ & & $\begin{array}{c}\text { Training } \\
\text { data }\end{array}$ & $\begin{array}{c}\text { Testing } \\
\text { data }\end{array}$ & Average \\
\hline $\mathrm{PH}$ & 178 & 7 & -5 & 5 & 100.00 & 85.38 & 92.69 \\
\hline DP & 120 & 7 & -3 & 5 & 100.00 & 83.08 & 91.54 \\
\hline $\mathrm{ZD}$ & 24 & 1 & 3 & 4 & 99.81 & 91.54 & 95.67 \\
\hline BDD & 192 & 3 & -3 & 4 & 100.00 & 88.46 & 94.23 \\
\hline $\mathrm{HVH}+\mathrm{DP}$ & 180 & 7 & -3 & 5 & 100.00 & 89.23 & 94.62 \\
\hline $\mathrm{ZD}+\mathrm{DP}$ & 144 & 3 & -3 & 4 & 100.00 & 88.46 & 94.23 \\
\hline $\mathrm{BDD}+\mathrm{ZD}$ & 216 & 3 & -3 & 4 & 100.00 & 90.00 & 95.00 \\
\hline $\mathrm{BDD}+\mathrm{HVH}$ & 252 & 5 & -3 & 3 & 100.00 & 87.69 & 93.85 \\
\hline $\mathrm{BDD}+\mathrm{DP}$ & 312 & 5 & -5 & 5 & 100.00 & 90.77 & 95.39 \\
\hline $\mathrm{BDD}+\mathrm{DH}$ & 310 & 7 & -5 & 5 & 100.00 & 82.31 & 91.15 \\
\hline
\end{tabular}

The results show that the third feature vector, which is zonal density feature (ZD), has the highest average accuracy. The value is achieved from the fourth fold of 5-fold cross validation with $C=2\left(2^{1}\right)$ and $\gamma=8\left(2^{3}\right)$. Thus, the zonal density feature is selected as an input of SVM classifier where parameter $C$ is two and parameter $\gamma$ is eight. Later, the reference data of SVM is taken from training data on the fourth fold.
Afterwards, the best feature vector and parameter are used to measure the accuracy of the numeral recognition of a set of kWh-numbers on stand kWh-meter. First, the stand kWhmeter are grouped based on the number of successful recognised number. Then, the total of each group is compared by the total of inputted stand kWh-meter. Based on Table 3, there are 8 of failed segmented of stand kWh-meters, therefore the total of inputted stand $\mathrm{kWh}-$ meter is 137 stand $\mathrm{kWh}$-meters. The results of the numeral recognition are shown in Table 4. The results show that the proposed system successfully recognised all of $\mathrm{kWh}$-numbers on stand $\mathrm{kWh}$ meter by $78.10 \%$ of accuracy.

Table 4. The result of numeral recognition

\begin{tabular}{ccc}
\hline $\begin{array}{c}\text { Total digit of successful } \\
\text { recognised number }\end{array}$ & $\begin{array}{c}\text { Total of stand } \\
\text { kWh-meter }\end{array}$ & Accuracy \\
\hline 5 & 107 & $78,10 \%$ \\
4 & 22 & $16,06 \%$ \\
3 & 8 & $5,84 \%$ \\
\hline
\end{tabular}

If the result in Table 4 is compared by Table 2, there are 2 stand $\mathrm{kWh}$-meter that have five segmented area but it is failed to recognise the number on all segmented area. Hence, there are increasing of the total stand $\mathrm{kWh}$-meter that have four segmented area. Some failed numeral recognition is caused by the movement of turnover number (shown in the fifth digit of the third image of Fig. 6) and clipped number (the fourth digit of the fourth image of Fig. 6).

\section{Conclusion}

The proposed system successfully detected and recognised the kWh-numbers on postpaid kWh-meter image, where the conditions of illumination and the stand $\mathrm{kWh}-$ meter position 
are not ideal, by using local thresholding for pre-processing, combination of vertical edge detection and morphology operation for location detection process, vertical-horizontal projections for segmentation process, SVM classifier with RBF kernel and zonal density feature as input for numeral recognition. The accuracy of the proposed system is $93.55 \%$ on the detection location process, $89.38 \%$ on the number area segmentation process, and $78.10 \%$ on numeral recognition process.

However, the proposed system is still constrained by the distance of image capturing, the movement of turnover number, clipped number and some noises which make the numbers on stand $\mathrm{kWh}$-meter are unclear. In future work, it is suggested to solve the distance of image capturing by measuring the ideal distance of image capturing so that the size of all image is similar. In addition, other constrains can be minimised by combining the features of numeral recognition in this study with other features, such as structural features.

\section{References}

1. E. Ardianto, V. Lusiana, and W. Hadikurniawati, "Rancang Bangun Aplikasi Pengolah Gambar Digital untuk Segmentasi Otomatis Lokasi Objek Angka pada Meter Listrik," J. Tek. Inf. Din., vol. 16, no. 2, pp. 110-117, 2011.

2. M. Setiawan, "Teknik Pengendalian Kualitas Pembacaan Angka kWhmeter Menggunakan I-MR (Individual-Moving Range) Control Chart," Lampung, 2010.

3. A. E. Shaputra and A. Nugraha, "Sistem Kerja Automatic Meter Reading dengan Menggunakan Media Power Line Carrier 220V di Kawasan Pondok Indah," Jakarta, 2011.

4. D. Pramaharsi, "Penanganan Teks 'PERIKSA' pada kWh-meter Prabayar di PT. PLN (Persero) Rayon Kota Yogyakarta," Universitas Gadjah Mada, 2013.

5. PT. PLN, "Term Of Reference (TOR) Pekerjaan Jasa Manajemen Billing PT. PLN Distribusi Jawa Tengah dan D.I. Yogyakarta Tahun 2013 s/d 2018." Semarang, 2013.

6. C. J. Lakshmi, D. A. J. Rani, D. K. S. Ramakrishna, and M. KantiKiran, "A Novel Approach for Indian License Plate Recognition System," Int. J. Adv. Eng. Sci. Technol., vol. 6, no. 1, pp. 10-14, 2011.

7. R. Gunawan, S. Suwarno, and W. Hapsari, "Penerapan Optical Character Recognition (OCR) untuk Pembacaan Meteran Listrik PLN," INFORMATIKA, vol. 10, no. 2, pp. 127-134, 2014.

8. A. Sudiarso and R. J. Merischaputri, "An Automation of Electricity Usage Reading on Postpaid kWh Meter using Kohonen-Type Artificial Neural Network," Int. J. Mining, Metall. Mech. Eng., vol. 1, no. 4, pp. 238-240, 2013.

9. R. J. Merischaputri, "Otomasi Pembacaan Data Penggunaan Listrik pada kWh-meter Pascabayar untuk Mengurangi Waktu Proses Pengambilan Data Menggunakan Pendekatan Jaringan Syaraf Tiruan Bertipe Kohonen," Universitas Gadjah Mada, 2013

10. R. J. Merischaputri, "Otomasi Pembacaan Data Penggunaan Listrik pada kWh Meter Pascabayar untuk Mengurangi Waktu Proses Pengambilan Data dan Perhitungan Tagihan Listrik Menggunakan Pendekatan Jaringan Syaraf Tiruan," Universitas Gadjah Mada, 2014.

11. J. Sauvola and M. Pietikäinen, "Adaptive document image binarization,"
Pattern Recognit., vol. 33, no. 2, pp. 225-236, 2000.

12. Y. Yang and H. Yan, "An Adaptive Logical Method for Binarization of Degraded Document Images," Pattern Recognit., vol. 33, no. 2000, pp. 787-807, 2000.

13. N. Ntogas and D. Veintzas, "A binarization algorithm for historical manuscripts," in Proceedings of the 12th WSEAS International Conference on Communications, 2008, pp. 41-51.

14. Y. Qiu, M. Sun, and W. Zhou, "License Plate Extraction Based on Vertical Edge Detection and Mathematical Morphology," in 2009 International Conference on Computational Intelligence and Software Engineering, 2009, pp. 1-5.

15. A. Wang, X. Liu, Y. Han, and C. Qi, "License Plate Location Algorithm Based on Edge Detection and Morphology," 2012 7th International Forum on Strategic Technology (IFOST). pp. 1-4, 2012.

16. T. S. Rajashree and T. K. Renugha, "Vehicle License Plate Detection using Vertical Edge Detection," Int. J. Eng. Res. Technol., vol. 3, no. 10, pp. 1225-1232, 2014.

17. B. Enyedi, L. Konyha, C. Szombathy, and K. Fazekas, "Strategies for fast license plate number localization," in Proceedings Elmar - International Symposium Electronics in Marine, 2004, pp. 579-584.

18. R. Chen and Y. Luo, "An Improved License Plate Location Method Based On Edge Detection," in Physics Procedia, 2012, vol. 24, pp. 13501356.

19. C. C. Lin and W. H. Huang, "Locating License Plate Based on Edge Features of Intensity and Saturation Subimages," Second Int. Conf. Innov. Comput. Inf. Control. ICICIC 2007, vol. 2, no. 59, pp. 2-5, 2008.

20. J. Jagannathan, A. Sherajdheen, R. M. Vijay Deepak, and N. Krishnan, "License Plate Character Segmentation Using Horizontal and Vertical Projection with Dynamic Thresholding," in 2013 IEEE International Conference on Emerging Trends in Computing, Communication and Nanotechnology, ICE-CCN 2013, 2013, pp. 700-705.

21. K. Parasuraman and P. V. Kumar, "An Efficient Method for Indian Vehicle License Plate Extraction and Character Segmentation," in IEEE International Conference on Computational Intelligence and Computing Research, 2010.

22. B. Santosa, "Tutorial Support Vector Machine." Surabaya, pp. 1-23, 2005.

23. K. Singh Siddharth, R. Dhir, and R. Rani, "Handwritten Gurmukhi Numeral Recognition using Different Feature Sets," Int. J. Comput. Appl., vol. 28, no. 2, pp. 20-24, 2011.

24. H. Pujiharsono, H. A. Nugroho, and O. Wahyunggoro, "The Stand Meter Extraction of kWh-meter," 2015 International Conference on Science in Information Technology (ICSITech). pp. 202-206, 2015.

25. R. Fisher, S. Perkins, A. Walker, and E. Wolfart, "Adaptive Thresholding," Hypermedia Image Processing Reference (HIPR), 2003. [Online]. Available: homepages.inf.ed.ac.uk/rbf/HIPR2/adpthrsh.htm. [Accessed: 23-Mar-2015].

26. D. Putra, "Penskalaan," in Pengolahan Citra Digital, Yogyakarta: Penerbit ANDI, 2010, pp. 159-162.

27. C.-W. Hsu, C.-C. Chang, and C.-J. Lin, "A Practical Guide to Support Vector Classification," National Taiwan University. 2010.

28. J. C. Platt, "Fast Training of Support Vector Machines Using Sequential Minimal Optimization," in Advances in Kernel Methods, 1998, pp. 4165 .

29. C.-W. Hsu and C.-J. Lin, "A Comparison of Methods for Multiclass Support Vector Machines," IEEE Transactions on Neural Networks, vol. 13, no. 2. pp. 415-425, 2002. 